\title{
Purposes of Performance Appraisal System: A Perceptual Study of Civil Servants in District Dera Ismail Khan Pakistan
}

\author{
Malik Ikramullah (Corresponding author) \\ Department of Public Administration, Gomal University \\ Dera Ismail Khan 29050, Pakistan \\ Tel: 92-966-750-122Ｅ-mail: ikramphdscholar@gmail.com \\ Bahadar Shah \\ Faculty of Law and Administrative Sciences, Hazara University Mansehra \\ Mansehra 21300, Pakistan \\ Tel: 92-997-414-146 E-mail: bahadarshah@hu.edu.pk \\ Shadiullah Khan \\ Department of Public Administration, Gomal University \\ Dera Ismail Khan 29050, Pakistan \\ Tel: 92-966-750-122Ｅ-mail: drshadiullah@yahoo.com \\ Faqir Sajjad ul Hassan \\ Department of Public Administration, Gomal University \\ Dera Ismail Khan 29050, Pakistan \\ Tel: 92-966-750-122Ｅ-mail: faqirphd@yahoo.com \\ Tariq Zaman \\ Department of Public Administration, Gomal University \\ Dera Ismail Khan 29050, Pakistan \\ Tel: 92-966-750-122Ｅ-mail: tariqazama@yahoo.com
}

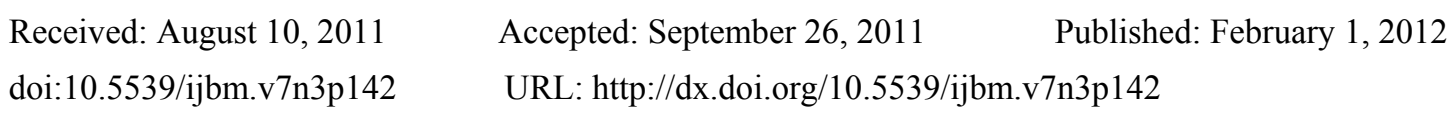

\begin{abstract}
Performance Appraisal System (PAS) in the civil service of Pakistan has been established to fulfill various purposes. Previously, this aspect of PAS in the civil service has not been investigated. In this study we examine perceptions of the civil servants regarding various purposes of the PAS. Data was collected from the civil servants working in the two departments of far flung district Dera Ismail Khan, Khyber Pakhtunkhwa. The results show that appraisees have mixed responses regarding purposes of PAS. It implies that appraisees are not fully aware to all the purposes of PAS, with exception of a sole purpose i.e. support to promotion decisions. In the article we discuss the factors affecting appraisees' perceptions about purposes of the appraisal system. Subsequently, we proffer few recommendations for making the appraisal system purposeful in minds of appraisees. Finally, we give directions for future research in the PAS of civil service.
\end{abstract}

Keywords: Performance Appraisal System, Performance appraisal purposes, Human Resource Decisions, Civil service 


\section{Introduction}

Today, almost every organization whether it is a public or private, needs to assess the performance of its employees. For instance, Wiese and Buckley (1998, p.233) contended that "everyone has had their performance appraised in some context". The formal system of assessing the performance of employees is called performance appraisal system (PAS). It is one of the important functions of human resource management (HRM) in any organization (Dulebohn \& Ferris, 1999). Moreover, PASs are established in organizations to fulfill many purposes, for instance, furnishing concerned authorities with information for making decisions, like, pay, promotion decisions, training \& development, and documentation for legal purposes (Dubinsky, Skinner, \& Whittler, 1989; Taylor, Tracy, Renard, Harrison, \& Carroll, 1995). Similarly, Nurse (2005) argued that in an organization PAS is important aspect of managerial control and various HRM functions are linked with it. The perceived utility of PAS depends on the achievement of various purposes for which it is designed and implemented in an organization (Huffman, Lisa \& Cain, 2000). Therefore, an effective and useful PAS must achieve the purposes for which it is executed in an organization.

Since long performance appraisal has taken attention of researchers in the area industrial organizational psychology (Holbrook, 1999). Research on how PAS is being used in organization (i.e. purpose achievement of PAS) is growing and eliciting mixed results (Boswell \& Boudreau, 2000). The literature reveals that PASs mostly don't satisfy the purposes for which they are established in work settings (Meyer, 1991). Moreover, PASs are not given due attention because appraisers regard performance assessment as an unproductive and unpleasant practice (Wiese \& Buckley, 1998). Likewise, appraisees are also not always happy with the PASs. They generally show dissatisfaction toward the appraisal process and also to other human resource (HR) decisions which are made on the basis of appraisal ratings (Milliman, Nason, Zhu, \& De Cieri, 2002). If employees perceive PAS unfair or they have negative attitudes toward the system, then there is a great possibility for development of such attitudes toward the whole organization (Whiting \& Kline, 2007). Consequently, inability of PAS to achieve its purposes affects whole organization.

When PAS is perceived as purposeless function then it loses worth in an organization and termed as vague activity. The system users (i.e. appraiser and appraisees) deem the system as a formality of appraisal form filling, which has no serious implications for their development and rewards. Thus, in PAS of an organization appraisal ratings must be linked with HR decisions, so that users perceive that the system has some utility and it is not a useless ritual of form filling.

In case of Public sector organizations, performance appraisal is still a serious problem (McEvoy, 1990). Likewise, in the civil service of Pakistan, PAS is also problematic and it has been criticized due to various flaws. In addition, PAS of civil service has been overlooked in various reforms attempts and it is difficult to find any progress in this particular area (National Commission for Government Reforms [NCGR], 2008).

The literature on PAS of Pakistani civil service is limited, only few studies have briefly discussed this HR function of the civil service (e.g. Civil Society Human and Institutional Development Programme [CHIP], 2005; Crisis Group Report, 2010; National Anti-Corruption Strategy [NACS], 2002; NCGR, 2008). However, the main focus of these studies was to illuminate overall issues associated with Pakistani civil service. To date, none of the study has explicitly investigated purposes of PAS in the civil service.

Nevertheless, few attempts have been made to improve the effectiveness of PAS in the civil service. But unfortunately these endeavors were limited only to revision of rating format. In contrast, Jacobs, Kafry, and Zedeck (1980) argued that PAS effectiveness depends not only on psychometric soundness of rating form, but also on PAS utilization criteria (i.e. purpose achievement) and qualitative criteria (i.e. reactions of the people involved in PAS). In the present study we are exploring single criterion i.e. civil servants' perceptions about the purposes of PAS.

This study spotlights the purposes for which PAS has been established in the civil service of Pakistan. Moreover, it seeks civil servants' perceptions about various purposes of PAS i.e. up to what extent PAS is achieving its predefined purposes. Thus, the article will give insight into PAS utility in eyes of the civil servants. Furthermore, it will give authorities a clear direction that on which purpose(s) the efforts should be made to tone up linkage of PAS with HR decisions. Ultimately, this will help to improve appraisees' perceptions about utility of appraisal system in the civil service of Pakistan.

The article starts with the overview of PAS and their purposes. Next the methods are discussed, then, it reports perceptual data gathered from appraisees. Finally, limitations of the study and directions for future research are presented. 


\section{Performance Appraisal System}

Performance appraisal is one of the intensively researched topics in the field of industrial/organizational psychology (Fletcher, 2001; Levy \& Williams, 1998). It is a formal process of employee monitoring (Cardy \& Dobbins, 1994; Murphy \& Cleveland, 1991) and usually involves "evaluating performance based on the judgments and opinions of subordinates, peers, supervisors, other managers and even workers themselves" (Jackson \& Schuler, 2003, p.455). Similarly, performance appraisal has been defined as "activities through which organizations seek to assess employees and develop their competence, enhance performance and distribute rewards" (Fletcher, 2001, p.473).

A performance appraisal system (PAS) consists of various interrelated elements involved in implementation, management, and communication of the events involved in performance appraisal (Walsh, 2003). Jawahar (2007) described that the performance appraisal system (PAS) deals with processes and procedures governing the performance appraisal in an organization. Previous research has found that PAS has strong linkage with various organizational and individual outcomes. For example, employee's job performance, organizational commitment (Colquitt, Conlon, Wesson, Porter, \& Ng, 2001), job satisfaction (Blau, 1999), and withdrawal intention (Greenberg, 1993). Nathan, Mohrman, and Milliman (1991) also contended that PAS can influence essential organizational outcomes like employee level of satisfaction and his/her on job performance.

In the PAS literature, it is well accepted that performance appraisal is a core HRM function of an organization (Dulebohn \& Ferris, 1999). Many organizational researchers accept the importance of performance appraisal (e.g. Borman, 1979; Landy \& Farr, 1980; Saal, Downey, \& Lahey, 1980). Likewise, Ilgen and Feldman (1983) contended that it is not possible for any organization to function successfully if it doesn't differentiate between good and poor performer in work settings. Moreover, PAS plays very important role in an organization because it gives sound base to record performance on a rating form, establishes mechanism for performance feedback, and justifies the decisions which are made on the basis of performance evaluations (Yeager, Rabin, \& Vocino, 1985).

PAS allows an organization to evaluate its employees' behavior and achievements over a specific period of time (DeVries, Morrison, Shullman, \& Gerlach, 1981). Moreover, it establishes a 'rational' mechanism for management to make various decisions regarding its employees' (Nurse, 2005). It creates performance feedback system between supervisor and employees (Mount, 1984). The primary goal of performance appraisal is to encourage employees' to change their behavior for performance improvement (Roberson \& Stewart, 2006). This happens when supervisor coaches/counsels employees, communicates performance expectations and motivates subordinates to perform optimally (Ahmed, 1999; Thomas \& Brentz, 1994). Thus, an effective PAS not only accurately assesses performance level of employees but also develops employees to meet the future work force requirement of an organization.

On the other hand, ineffective PAS can be damaging for organization. Poorly managed PAS can cause various problems for organization, like, disputes among employees and management, anger in staff. Moreover, organization and supervisor both are perceived by employees as unfair and discriminating (Montague, 2007). Therefore, PAS should be carefully designed and properly implemented in work settings. Additionally, upper management should also make HR decisions fairly on the basis of appraisal ratings. So that employees could perceive that the system is not merely a formality, instead, it supports various important decisions in work settings.

\subsection{Purposes of Performance Appraisal System}

PASs are being administered for fulfilling various purposes in organizations, for instance, to enhance employee performance and productivity (Cardy \& Dobbins, 1994; Murphy \& Cleveland, 1991), develop employees to enhance their skills (Cook \& Crossman, 2004) and to develop those performance areas where employee has low ratings (Flint, 1999). Boswell and Boudreau (2000) argued that PASs are being used for administrative decisions relating to (salary, promotion, retention or termination, layoff) and developmental decisions like (training of employees, furnishing appraisee with regular performance feedback, employees' transfers, determining employees strengths and weaknesses). Likewise, Cleveland, Murphy, and Williams (1989) identified following four purposes of PAS:

- Between employees (setting pay package, promotion to higher grades, termination from service, identifying the poor performer).

- Within an employee (identifying weaknesses \& strengths, employee training needs etc). 
- System maintenance (helps in evaluation of personnel system, organizational goal attainment, organizational needs for training and developmental needs of organization).

- Documentation (documenting personnel actions and having record in case of legal proceedings).

- Doleh \& Weir (2007) in their empirical study found that PASs had a moderate impact on the above mentioned four functions identified by Cleveland et al., (1989).

The purposes of performance appraisal affects supervisor's motivation to rate his/her subordinates. Boswell and Boudreau, (2002) argued that supervisor rates subordinates leniently if ratings are used for developmental purpose instead of salary decisions. Conversely, Cleveland and Murphy (1992) argued that supervisor's motivation to inflate ratings is high if administrative decisions like pay raises, promotion are made on the basis of ratings and low if ratings are used for other purposes like feedback and development. Moreover, Boswell and Boudreau (2002) found that employees showed positive attitude for appraiser and appraisal, when PAS was used for developmental purposes, while these attitudes were not present when PAS was used for administrative purposes.

Since PAS evaluates employees job performance and aids to crucial HR decisions, therefore naturally employees get emotionally involved in it. For instance, Thompson and Dalton (1970, p. 150) stated that PAS is "one of the most emotionally charged activities in business life". Furthermore, Decotiis and Petit (1978) asserted that inextricable relationship exists between performance appraisal purposes and its consequences for appraiser and appraisee. Supervisors and subordinates don't react positively if the stated purpose of performance appraisal is different from the perceived results (Gabris \& Ihrke, 2001). Nurse (2005, p. 1182) argued that "if employees consistently meet and exceed performance standards and requirements but are not appropriately rewarded, through increased pay or promotion or other appropriate forms of recognition, the linkage between performance appraisal and employee career advancement is weakened".

Likewise, Schellhardt (1996) asserted that complaints increases and satisfaction is decreased when employee perceives no value of organization's PAS. According to Keeping and Levy (2000), perceived accuracy and utility of PAS are associated with appraisal satisfaction. Youngcourt, Leiva, and Jones (2007) contended that irrespective of intended purpose of PAS, perceived purpose will influence appraisees' attitudes toward the system. Therefore, there should be a clear purpose behind establishing PAS and it must be achieved.

\section{Performance Appraisal in the Civil Service of Pakistan}

Just like other organizations, in the civil service of Pakistan PAS is established to aid various HR decisions. Core purposes of PAS are to provide "aid to selections for training, appointments/transfers, promotions, confirmations or screening of officials" (Pakistan Public Administration Research Center [PPARC], 2004, p.1). In the civil service main mechanism for assessing the performance of public officer is 'Performance Evaluation Report' (PER) formerly called (ACR) 'Annual Confidential Report' (Asian Development Bank [ADB, Department for International Development [DFID] \& World Bank, 2004).

For improving the PAS in civil service, few unfocused attempts have been made which were only limited to rating format changes. Until now, performance appraisal format has been revised more than four times (i.e. 1949, 1960, 1963, 1982 and 2000) since independence of Pakistan. Last attempt to revise format was made in 2000 in President Pervaz Musharaf regime (PPARC, 2004). On the other hand, problems identified by few studies still remained unaddressed. For instance, CHIP (2005) reported that in the civil service of Pakistan, effective performance evaluation system doesn't exist and it has been ostracized as unproductive system as far as the modern HRM practices are concerned. Similarly, in PAS of the civil service, slight consideration is given to appraisees' actual performance and training \& developmental needs (Alam, Watson, \& Alvi, 2008). In addition, NACS (2002) also asserted that the appraisal system in the civil service has failed to create a results-oriented and answerable organizational culture in the public sector organizations.

It is clear from the above discussion that PAS in the civil service of Pakistan has not been investigated thoroughly. Moreover, efforts for improving the system were limited only to format changes. Although, format improvement can increase validity and reliability of rating instrument, but it can't improve other problems in the system. Likewise, McEvoy (1990) also argued that improvements in appraisal forms can't change the perceptions of the system users'. Therefore, in the civil service, rating format changes neither improve appraisal purposes achievement, nor commitment from top management towards that system. Therefore, we argue that the appraisal system should be investigated in terms of all aspects which include: psychometric soundness, users' fairness perceptions and perceived utility or purpose achievement. 


\section{Method}

\subsection{Procedures}

For the study, data was collected with questionnaire distributed among the employees working in two public sector organizations in District Dera Ismail Khan, Khyber Pakhtunkhwa, Pakistan. The respondents were gazetted employees (civil servants) working in the Basic Pay Scale (BPS) 16 to 19, whose performance needs to be appraised annually by superior officers. For the data collection from eligible employees, we personally administered questionnaire with a covering letter explaining purpose of the study. Researchers also provided envelope to respondents so that confidentiality of their responses could be ensured. Moreover, during data collection process participants were encouraged to complete questionnaire in break time and they were also requested to immediately return back questionnaire after completion. Respondents were also told to fill questionnaire as an appraisee in the PAS.

\subsection{Participants}

The questionnaire was distributed among 273 eligible employees. The survey resulted in data from 261 employees with response rate of (95\%) in which 259 questionnaire were usable for data analysis. In participant 212 were males and 47 females. Employees working in BPS 16, 17, 18 and 19 were 172, 73, 10 and 4 respectively. Majority of the respondents belonged to race group Saraiki 192, while 228 employees reported their sect Sunni. In respondents 28 were also performing duties as an appraiser in their departments. Majority of the respondents 118 were between the age groups of 36-45. While majority of the respondents 85 have working experience (in department) between 6-10 years.

\subsection{Measures}

Perceptions regarding the two purposes of the PAS were measured with two scales "Administrative Purpose" and "Developmental Purpose" consisting of nine items. Items of both scales were obtained from the previous research (e.g. Cleveland et al., 1989; Longenecker, Liverpool, \& Wilson, 1988; Youngcourt et al., 2007). The scale "Administrative Purpose" contains four items, for example, "PAS guides promotion of an employee" and "PAS aids decisions regarding transfer of an employee". While the scale "Developmental Purpose" consists of five items, for example, "PAS identifies individual's strengths" and 'PAS identifies employees' weaknesses". However, few items were also added according to the requirement of the study, for instance, "PAS aids decisions regarding transfer of an employee", "PAS helps to make decisions regarding termination of poor performer". Except the demographic variables, other items were measured on five-point Likert response scales with 1(Strongly Disagree) to 5 (Strongly Agree). Moreover, for interpreting results, researchers used interpretive scale which is: 1.50 or less $=$ Strongly Disagree; $1.51-2.5=$ Disagree; $2.51-3.49=$ Neither Agree nor Disagree; 3.50 $-4.49=$ Agree; and 4.5 or greater $=$ Strongly Agree .

\section{Results}

In the present study apraisees' responses about perceived purpose of PAS (i.e. perceived developmental purposes and perceived administrative purposes) have been recorded. In the scale "Administrative Purposes", appraisees' recoded agree response for one item, neutral for one item, while they recoded disagreement for two items (see table 1.). The overall response of the scale Administrative purposes was "Neither Agree nor Disagree" $($ mean $=2.95)$ (see table1).

\section{Insert Table 1 here}

In the scale measuring appraisees' perceptions about developmental purposes of PAS, appraisees' showed agreement for two items while neutral i.e. "Neither Agree nor Disagree" for three items (see table 2). The overall response fall in category "Neither Agree nor Disagree" (mean 3.46) (see table 2). Therefore, the results showed that appraisees' perceptions about PAS are not clear. This might be due to lack of information regarding purposes of PAS or the appraisal system's failure to achieve the defined purposes. Thus, the appraisal system is not being used explicitly for supporting HR decisions in the civil service of Pakistan.

Insert Table 2 here

\section{Discussion}

The present study showed mixed responses i.e. neutral, agree and disagree of appraisees about the purposes of PAS in the civil service of Pakistan. So the civil servants are not very much clear about the purposes of PAS. This implies that practically the system is not completely supporting HR decisions or fulfilling those purposes for which it has been designed and implemented in the civil service. Conversely, the formal rules regarding PAS in the civil service say that PAS has been established to support various HR decisions. Our results have been 
supported by previous research of CHIP (2005), which reported that in the civil service of Pakistan, effective PAS doesn't exist and it has failed to operate in accordance with the modern HRM practices.

In view of the civil servants, main purpose of PAS is to support promotion decisions, which are highly dependent on PERs i.e. appraisal reports of officers. NCGR (2008) also reported that too much weightage is given to PER for promotion of civil servants. An officer cannot be promoted until and unless his/her PERs are up to date and complete in all respects. Sometimes, officers' are unable to be considered for promotion due to incomplete appraisal reports. One instance happened in 2010, twenty officers were unable to get promotion to higher grades due to incomplete PERs (News Reporter, 2010).

We found that appraisees also perceive that PAS is not being used for recording their performance accurately. As PERs are not prepared regularly at the end each year to record employees' performance during the year under review, therefore, this discrepancy ultimately affects promotion decisions of civil servants. Furthermore, same PER is being used to appraise the performance of civil servants working in the similar grades in different departments. Consequently, it is unable to record accurately performance of civil servants working in different jobs. For instance, same PER is used to assess the performance of doctors and teachers, who have different job descriptions.

Civil servants have not showed agreement with the purpose of PAS to aid employee's transfer decisions. As in practice, civil servants are transferred from one post to another either in routine transfers within the department or due to outside influences (e.g. political). Moreover, in some cases civil servants also makes personal influences to get desired posts. In addition to above, it has also been found that officers compel their appraisers to give higher ratings, so that they can get desired benefits in terms of promotion or transfer to other posts. Similar, evidence has been given in the report of NCGR (2008) that appraisees sometimes compel their superiors to award them good rating, so that they can qualify for promotions.

Similarly, in the civil service appraisees perceive no role of PAS in termination of officer from the post. Our results have been supported by previous research, for example, NASC $(2002$, p.31) states that "civil servants don't perceive that officers' remuneration or continuance in post depends on the performance evaluation".

Furthermore, our results showed that appraisees perceive no obvious role of PER in training and development of officers. Usually, PASs identify performance deficiencies in employees and then training programs are designed to overcome those deficiencies. So an organization helps employees to overcome performance weaknesses and also enhance working skills, in this way organization can manage internal labor market to meet future requirements as well. However, in the civil service of Pakistan employees are given various trainings but these are not based on any specific training need assessment program, therefore, trainings are unfocused. Additionally, in practice, civil servants are trained by performing on their jobs and major sources of training are superiors and peers. Thus, in the civil service learning by doing is the primary source of skill development and overcoming performance weaknesses. Our argument is in accordance with the contention of Alam, Watson, and Alvi (2008) that in the civil service of Pakistan slight consideration is given to appraisee's actual performance and training and developmental needs.

The present research showed that appraisees have no clear perceptions about the role of PAS in performance feedback and appraisal rating feedback. In the civil service of Pakistan, PAS was previously confidential, but recently it has been declared as restricted and appraisees can access their appraisal reports. However, still it has been perceived confidential (F. Khan [E.T.O] personal communication April 21, 2010). Due to confidentiality appraisees are unable to get adequate performance feedback. Likewise, they are unable to know where they stand with respect to preset goals/targets achievement. Furthermore, there is no provision of appraisal review meeting in the rules, so that appraisees can formally get performance feedback from appraiser. Nevertheless, appraisees get informal performance feedback from superiors during their various interactions throughout the rating periods.

Thus, the perceptions of civil servants showed that PAS purposes are not clear in their minds. The main reason might be less information about the purposes of the system or PAS's weak linkage with its purposes and inability to support HR decisions. Therefore, it is required that the management should clearly disseminate information about the purposes of PAS in the civil service of Pakistan. Moreover, management should explicitly link HR decisions with PAS. This will develop perceptions in appraisees that PAS has some purposes for which it has been practiced in the civil service.

\section{Future Research}

As there is very limited research on PAS of the civil service, we recommend that future researchers should investigate this topic more deeply. Future research should study the impacts perceived purpose on employee 
satisfaction with PAS and relationship of PAS purposes with other individual and organizational outcomes. Similarly, future efforts should investigate up to what extent administrative and developmental purposes of PAS are associated with each other. Since the position also needs to be reengineered with the passage of time and advancement in technology. Therefore, future studies should explore whether another purpose should be introduced in PAS i.e. to determine various changes in structure of the work associated with a position.

\section{Limitations}

Like other studies this research has few limitations. First limitation is that this research has been conducted in two departments of far-flung area of Khyber Pakhtunkhwa; therefore the results may not be generalized to civil servants (appraisees) working in other Departments/Districts of Khyber Pakhtunkhwa or to civil servants working in the country. Another limitation is that it has determined perceptions of PAS purpose of appraisees' who were in BPS 16-19. Therefore, it was unable to measure the perceptions of appraisees working in scales lower than the BPS 16 and above the BPS 19.

\section{Conclusion}

Current study has provided useful insight into appraisees' perceptions about the purposes of PAS in the civil service of Pakistan. The rules of civil service say that PAS has to support important developmental and administrative purposes (PPARC, 2004). Conversely, results showed that appraisees are not in agreement with all the items of the scales developmental purposes and administrative purposes. Furthermore, study reports that in eyes of civil servants PAS is not performing optimally and unable to achieve the desired results. Ultimately, these flaws in the system engender negative perceptions in the users' (i.e. appraisers and appraisees), and also makes the system worthless. In the civil service, there are various examples, which show that PAS has not been given due importance by its users. For instance, supervisors don't conduct appraisal regularly and most of the appraisal reports of appraisees remain incomplete (PPARC, 2004). Similarly, appraisees only initiate their PER when they need promotion.

The civil servants' negative perceptions of the purpose of PAS have very serious implications. According to Schraeder, Becton, and Portis (2007), a formal PAS can be damaging if it is not utilized properly. Thus, upper level management in the civil service should take serious steps to ensure that the PAS fulfill its purposes. Likewise, it must provide support in making critical HR decisions in the civil service. This will develop appraisees' perceptions that the system is used for accomplishing specified purposes. Moreover, appraisees will perceive that their on job performance is being noticed and hard work never goes unrewarded. Ultimately, they will have positive reactions toward PAS and the civil service.

\section{References}

Ahmed, S. (1999). The emerging measure of effectiveness for human resource management: An exploratory study with performance appraisal. The Journal of Management Development, 18(6), 543-556. http://dx.doi.org/ $10.1108 / 02621719910279644$

Alam, S. M., Watson, D. A., \& Alvi, M. S. (2008). Human resource management for good governance: Building local government capacity for effective service delivery (Report). Faisalabad, Pakistan: City District Government Faisalabad.

Asian Development Bank (2004). Review of governance and public management for Srilanka. Manila: Author.

Asian Development Bank, Department for International Development \& World Bank (2004). Devolution in Pakistan. Islamabad, Pakistan: Author.

Blau, G. (1999). Testing the longitudinal impact of work variables and performance appraisal satisfaction on subsequent overall job satisfaction. Human Relations, 52(8), 1099-1113. http://dx.http://dx.doi.org/ 10.1023/A:1016987725663

Borman, W. C. (1979). Format and training effects on rating accuracy and rater errors. Journal of Applied Psychology, 64(4), 410-421. http://dx.doi.org/10.1037/0021-9010.64.4.410

Boswell, W. R., \& Boudreau, J. W. (2002). Separating the developmental and evaluative performance appraisal uses. Journal of Business and Psychology, 16(3), 391-412. http://dx.doi.org/10.1023/A:1012872907525

Boswell, W. R., \& Boudreau, J. W. (2000). Employee satisfaction with performance appraisals and appraisers: The role of perceived appraisal use. Human Resource Development Quarterly, 11(3), 283-299.

Cardy, R. L., \& Dobbins, G. H. (1994). Performance appraisal: Alternative perspectives. Cincinnati, OH: South Western Publishing Company. 
Civil Society Human and Institutional Development Programme (2005). Needs assessment for service delivery capacity building at the district level: District Swabi (NWFP) (Swabi). Islamabad: Author.

Cleveland, J. N., \& Murphy, K. R. (1992). Analyzing performance appraisal as goal-directed behavior. In G. Ferris \& K. Rowland (eds.), Research in Personnel and Human Resources Management, (vol.10, pp. 121-185). Greenwich, CT: JAI Press.

Cleveland, J. N., Murphy, K. R., \& Williams, R. E. (1989). Multiple uses of performance appraisal: Prevalence and correlates. Journal of Applied Psychology, 74(1), 130-135.

Colquitt, J. A., Conlon, D. E., Wesson, M. J., Porter, C., \& Ng, K. Y. (2001). Justice at the millennium: A meta-analytic review of 25 years of organizational justice research. Journal of Applied Psychology, 86(3), 425-445. http://dx.doi.org/10.1037/0021-9010.87.4.611

Commission on Administrative Restructuring (1999). Re-engineering of the federal government organizations (Report). Islamabad, Pakistan: Author.

Cook, J., \& Crossman, A. (2004). Satisfaction with performance appraisal systems: A study of role perceptions. Journal of Managerial Psychology, 19(5), 526-541. http://dx.doi.org/10.1108/02683940410543605

Crisis Group Asia Report $\mathrm{N}^{\circ} 185$ (2010). Reforming Pakistan's civil service. [Online] Available: http://www.crisisgroup.org/ /media/Files/asia/south-asia/pakistan/185\%20Reforming\%20Pakistans\%20Civil\%2 OService.ashx

Decotiis, T., \& Petit, A. (1978). The performance appraisal process: A model and some testable propositions. The Academy of Management Review, 3(3), 635-646.

DeVries, D. L., Morrison, A. M., Shullman, S. L., \& Gerlach, M. L. (1981). Performance appraisal on the line. Greensboro, North Carolina: Center for Creative Leadership.

Doleh, J. A., \& Weir, D. (2007). Dimensions of performance appraisal systems in Jordanian private and public organizations. International Journal of Human Resource Management, 18(1), 75-84. http://dx.doi.org/10.1080/09585190601068334

Dubinsky, A. J., Skinner, S. J., \& Whittler, T. E. (1989). Evaluating sales personnel: An attribution theory perspective. Journal of Personal Selling and Sales Management, 9(2), 9-21.

Dulebohn, J. H., \& Ferris, G. R. (1999). The role of influence tactics in perceptions of performance evaluations' fairness. Academy of Management Journal, 42(3), 288-303.

Fletcher, C. (2001). Performance appraisal and management: The developing research agenda. Journal of Occupational and Organizational Psychology, 74(4), 473-487. http://dx.doi.org/10.1348/096317901167488

Flint, D. H. (1999). The role of organizational justice in multi-source performance appraisal: Theory based applications and directions for research. Human Resource Management Review, 9(1), 1-20. http://dx.doi.org/10.1016/S1053-4822(99)00009-1

Gabris, G. T., \& Ihrke, D. M. (2001). Does performance appraisal contribute to heightened levels of employee burnout? The results of one study. Public Personnel Management, 30(2), 157-172.

Greenberg, J. (1993). Justice and organizational citizenship: A commentary on the state of science. Employee Responsibility and Rights Journal, 6(3), 249-256. http://dx.doi.org/10.1007/BF01419448

Holbrook, R. L. (1999). Managing reactions to performance appraisal: The influence of multiple justice mechanisms. Social Justice Research, 12(3), 205-221. http://dx.doi.org/10.1023/A:1022196301372

Huffman, C., Lisa, B. \& Cain, L. B. (2000). Effects of considering uncontrollable factors in sales force $\begin{array}{lllll}\text { performance } \quad \text { evaluation. } & \text { Psychology } \quad \& \quad \text { Marketing, } & \text { 17(9), } & \text { 799-833. }\end{array}$ http://dx.doi.org/10.1002/1520-6793(200009)

Ilgen, D. R., \& Feldman, J. M. (1983). Performance appraisal: A process focus. Research in Organizational Behavior, 5(1), 141-197.

Jackson, S., \& Schuler, R. S. (2003). Managing human resources through strategic partnership (8th ed.). Canada: Thompson.

Jawahar, I. M. (2007). The Influence of perceptions of fairness on performance appraisal reactions. Journal of Labor Research, 28(4), 735-754. http://dx.doi.org/10.1007/s12122-007-9014-1 
Keeping, L. M., \& Levy, P. E. (2000). Performance appraisal reactions: Measurement, modeling, and method bias. Journal Applied Psychology, 85(5), 708-723. http://dx.doi.org/10.1037/0021-9010.85.5.708

Landy, F. J., \& Farr, J. L. (1980). Performance rating. Psychological Bulletin, 87(1), 72-107.

Levy, P. E., \& Williams, J. R. (1998). The role of perceived system knowledge in predicting appraisal reactions, job satisfaction, and organizational commitment. The Journal of Organizational Behavior, 19, 53-65. http://dx.doi.org/10.1002/(SICI)1099-1379(199801)

Longenecker, C. O., Liverpool, P. R., \& Wilson, K. Y. (1988). An assessment of manager/ subordinate perceptions of performance appraisal effectiveness. Journal of Business and Psychology, 2(4), 311-320. http://dx.doi.org/ 10.1007/BF01013763

McEvoy, G. M. (1990). Public sector managers' reactions to appraisals by subordinates. Public Personnel Management, 19(2), 201-212.

Meyer, H. H. (1991). A Solution to the performance appraisal feedback enigma. Academy of Management Executives, 5(1), 68-76.

Milliman, J., Nason, S., Zhu, C., \& De Cieri, H. (2002). An exploratory assessment of the purposes of performance appraisals in North and Central America and the Pacific Rim. Asia Pacific Journal of Human Resources, 40(1), 105-122. http://dx.doi.org/10.1002/hrm.10021

Montague, N. (2007). The performance appraisal: A powerful management tool. Management quarterly summer, 48(2), 40-53

Mount, M. K. (1984). Psychometric Properties of Subordinate Ratings of Managerial Performance. Personnel Psychology, 37(4), 687-702. http://dx.doi.org/10.1111/j.1744-6570.1984.tb00533.x

Murphy, K. R., \& Cleveland, J. N. (1991). Performance Appraisal: An Organizational Perspective. Boston: Allyn and Bacon.

Murphy, K. R., \& Cleveland, J. N. (1995). Understanding Performance Appraisal: Social, Organizational and Goal-Based Perspectives. Thousand Oaks, CA: Sage.

Nathan, B. R., Mohrman, A. M., \& Milliman, Jr. J. (1991). Interpersonal Relations as a Context for the Effects of Appraisal Interviews on Performance and Satisfaction: A Longitudinal Study. The Academy of Management Journal, 34(2), 352-369.

National Accountability Bureau. (2002). National anti-corruption strategy. Islamabad, Pakistan: Author.

National Commission for Government Reforms (2008). Reforming the government in Pakistan (Report). Islamabad, Pakistan: Author.

News Reporter (2010, August 1). Promotion of officers to grade 18. Daily Mashriq, p. 1.

Nurse, L. (2005). Performance appraisal, employee development and organizational justice: Exploring the linkages. The International Journal of Human Resource Management, 16(7), 1176-1194. http://dx.doi.org/10.1080/09585190500144012

Pakistan Public Administration Research Center. (2004). A guide to performance evaluation. Islamabad, Pakistan: Establishment Division.

Roberson, Q. M., \& Stewart, M. M. (2006).Understanding the motivational effects of procedural and informational justice in feedback processes. British Journal of Psychology, 97(3), 281-298. http://dx.doi.org/10.1348/000712605X80146.

Saal, F. E., Downey, R. G., \& Lahey, M. A. (1980). Rating the ratings: Assessing the psychometric quality of rating data. Psychological Bulletin, 88(2), 413-428. http://dx.doi.org/10.1037/0033-2909.88.2.413

Schellhardt, T. D. (1996, November 19). It's time to evaluate your work, and all involved are groaning. Wall Street Journal, p. A1.

Schraeder, M., Becton, B. J., \& Portis, R. (2007). A critical examination of performance appraisals an organization's friend or foe? The Journal for Quality and Participation, 30(1), 20-25.

Taylor, M. S., Tracy, K. B., Renard, M. K., Harrison, J. K., \& Carroll, S. J. (1995). Due process in performance appraisal: A quasi-experiment in procedural justice. Administrative Science Quarterly, 40(3), 495-523.

Thomas, S. L., \& Bretz, R. D., Jr. (1994). Research and practice in performance appraisal: Evaluating performance in America's largest companies. SAM Advanced Management Journal, 59 (2), 28-37. 
Thompson, P. H., \& Dalton, G. W. (1970). Performance appraisal: Managers beware. Harvard Business Review, 48, 149-157.

Walsh, M. B. (2003). Perceived fairness of and satisfaction with employee performance appraisal. Unpublished PhD Dissertation, Louisiana State University and Agricultural and Mechanical College, Louisiana, United States of America.

Whiting, H. J. Theresa J. B., \& Kline, T. J. (2007). Testing a model of performance appraisal fit on attitudinal outcomes. The Psychologist-Manager Journal, 10(2), 127-148.

Wiese, D. S., \& Buckley, M. R. (1998). The evolution of the performance appraisal process. Journal of Management History, 4(3), 233-249. http://dx.doi.org/10.1108/13552529810231003

Yeager, S. J., Rabin, J., \& Vocino, T. (1985). Feedback and administrative behavior in the public sector. Public Administration Review, 45(5), 570-575.

Youngcourt, S. S., Leiva, P. I., \& Jones, R. G. (2007). Perceived purposes of performance appraisal: Correlates of individual and position focused purposes on attitudinal outcomes. Human Resource Development Quarterly, 18(3), 315-343. http://dx.doi.org/org/10.1002/hrdq.

Table 1. Appraisees' Perceptions of Administrative Purposes

\begin{tabular}{|l|l|l|l|}
\hline Item & Mean & $\begin{array}{l}\text { Standard } \\
\text { Deviation }\end{array}$ & $\begin{array}{l}\text { Response } \\
\text { Category }\end{array}$ \\
\hline $\begin{array}{l}\text { Performance evaluation system of my department guides } \\
\text { promotion of an employee. }\end{array}$ & 3.54 & 1.135 & Agree \\
\hline $\begin{array}{l}\text { Performance evaluation system of my department aids decisions } \\
\text { regarding transfer of an employee. }\end{array}$ & 2.47 & 1.271 & Disagree \\
\hline $\begin{array}{l}\text { Performance evaluation system of my department documents and } \\
\text { recognizes employee performance. }\end{array}$ & 3.42 & 1.212 & $\begin{array}{l}\text { Neither Agree } \\
\text { Nor Disagree }\end{array}$ \\
\hline $\begin{array}{l}\text { Performance evaluation system of my department helps to make } \\
\text { decisions regarding termination of poor performer. }\end{array}$ & 2.39 & 1.147 & Disagree \\
\hline Overall Score & 2.95 & .87712 & $\begin{array}{l}\text { Neither Agree } \\
\text { Nor Disagree }\end{array}$ \\
\hline
\end{tabular}

Table 2. Appraisees' Perceptions of Developmental Purposes

\begin{tabular}{|l|l|l|l|}
\hline Item & Mean & $\begin{array}{l}\text { Standard } \\
\text { Deviation }\end{array}$ & $\begin{array}{l}\text { Response } \\
\text { Category }\end{array}$ \\
\hline $\begin{array}{l}\text { Performance evaluation system of my department identifies } \\
\text { individual strengths. }\end{array}$ & 3.57 & 1.084 & Agree \\
\hline $\begin{array}{l}\text { Performance evaluation system of my department identifies } \\
\text { employees' weaknesses. }\end{array}$ & 3.51 & 1.104 & Agree \\
\hline $\begin{array}{l}\text { Performance evaluation system of my department provides } \\
\text { guidance about the area in which employee needs training. }\end{array}$ & 3.39 & 1.242 & $\begin{array}{l}\text { Neither Agree } \\
\text { Nor Disagree }\end{array}$ \\
\hline $\begin{array}{l}\text { Performance evaluation system of my department is used to } \\
\text { provide feedback about employee performance. }\end{array}$ & 3.49 & 1.166 & $\begin{array}{l}\text { Neither Agree } \\
\text { Nor Disagree }\end{array}$ \\
\hline $\begin{array}{l}\text { Performance evaluation system of my department lets } \\
\text { employees know where they stand with respect to goal } \\
\text { achievement. }\end{array}$ & 3.35 & 1.348 & $\begin{array}{l}\text { Neither Agree } \\
\text { Nor Disagree }\end{array}$ \\
\hline Overall Score & 3.46 & 1.01218 & $\begin{array}{l}\text { Neither Agree } \\
\text { Nor Disagree }\end{array}$ \\
\hline
\end{tabular}

